\title{
Dynamics of neuromodulatory feedback determines frequency modulation in respiratory network
}

\author{
Natalia Toporikova ${ }^{1,2^{*}}$, Robert J Butera ${ }^{1,2}$ \\ From Twenty First Annual Computational Neuroscience Meeting: CNS*2012 \\ Decatur, GA, USA. 21-26 July 2012
}

Neuromodulators, such as amines and neuropeptides, alter the activity of neurons and neuronal networks. In this work, we investigate how neuromodulators which activate Gq-protein second messenger systems can modulate the frequency of bursting neurons in a critical portion of the respiratory neural network, the pre-Bötzinger complex $(\mathrm{pBC})$. These neurons are a vital part of the ponto-medullary neuronal network, which generates a stable respiratory rhythm, whose frequency is modulated by neuromodulator release from nearby Raphe nucleus. Using a simulated 50-cell network of excitatory connected pBC neurons with a heterogeneous distribution of persistent sodium conductance and ER Ca2+, we determined conditions for frequency modulation in such network by simulating interaction between Raphe and $\mathrm{pBC}$ nuclei. We found that the positive feedback between the Raphe excitability and $\mathrm{pBC}$ activity induces frequency modulation in the $\mathrm{pBC}$ neurons. In addition, the frequency of the respiratory rhythm can be modulated via phasic release of excitatory neuromodulators from the Raphe nucleus. We further predict that the application of a Gq antagonist will eliminate this frequency modulation by Raphe and keep the network frequency constant and low. In contrast, application of a Gq agonist will result in a high frequency for all levels of Raphe stimulation. Our modeling results also suggest that high $[\mathrm{K}+]$ requirement in respiratory brain slice experiments may serve as a compensatory mechanism for low neuromodulatory tone.

\footnotetext{
* Correspondence: ntoporikova3@gatech.edu

'Laboratory for Neuroengineering, Georgia Institute of Technology, Atlanta, GA, 30332-0250, USA
}

Full list of author information is available at the end of the article

\section{Author details}

'Laboratory for Neuroengineering, Georgia Institute of Technology, Atlanta, GA, 30332-0250, USA. ${ }^{2}$ School of Electrical and Computer Engineering, Georgia Institute of Technology, Atlanta, GA, 30332-0250, USA.

Published: 16 July 2012

doi:10.1186/1471-2202-13-S1-P175

Cite this article as: Toporikova and Butera: Dynamics of neuromodulatory feedback determines frequency modulation in respiratory network. BMC Neuroscience 2012 13(Suppl 1):P175.
Submit your next manuscript to BioMed Central and take full advantage of:

- Convenient online submission

- Thorough peer review

- No space constraints or color figure charges

- Immediate publication on acceptance

- Inclusion in PubMed, CAS, Scopus and Google Scholar

- Research which is freely available for redistribution

\section{() Biomed Central}

\section{Biomed Central}

